Journal Of Al-Azhar University Engineering Sector

Vol. 14, No. 51, April, 2019, 643-652

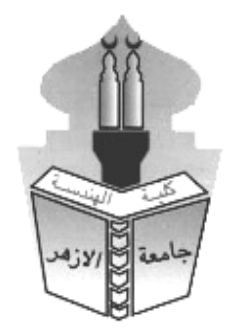

\title{
FORM OF URBAN AND ARCHITECTURE AFTER THE REVOLUTION OF 25 JANUARY 2011 IN EGYPT
}

\author{
Yousef Omar EI Rafie \\ Architecture, FUE, Future University in Egypt

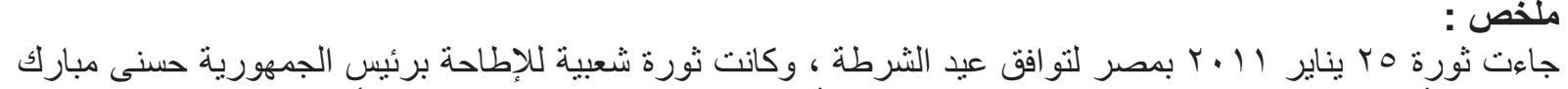

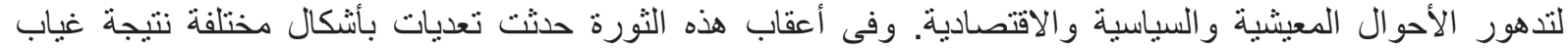

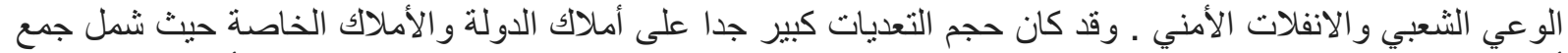

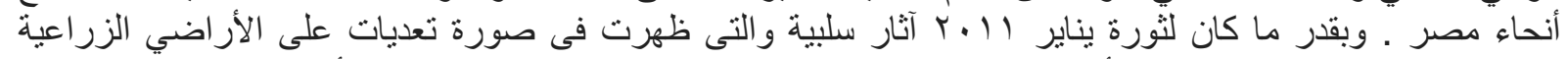

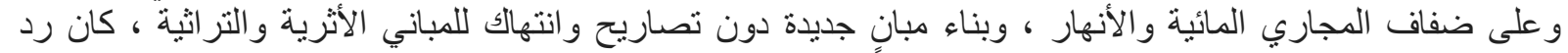

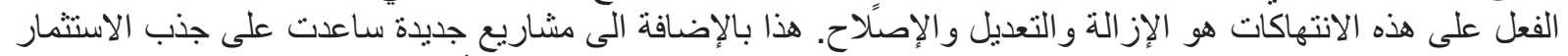

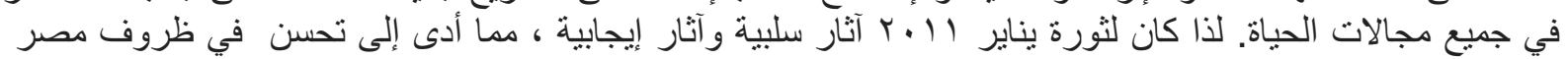 \\ الاقتصادية و السياسية.
}

\begin{abstract}
The revolution of January 25, 2011 in Egypt takes place with the Police Day, and was a popular revolution to remove President Hosni Mubarak due to the deterioration of living conditions, political and economic. During this revolution, violations was occurred in various forms due stress of life and not providing a decent life. Egypt is the second largest country in the population after Nigeria in Africa about 100 million people live on the banks of the River Nile on an area of about 40 thousand square kilometers, and where the rates of poor people to $80 \%$. The scale of violations was very high on Government and private property, including most of Egypt sites. UNESCO wanted to remove some of Egypt's archeological sites from the World Heritage List as a result of the deterioration of the situation due to the January 2011 revolution, the deterioration of some archaeological sites and the violation of them.

And To activate international cooperation to uphold local and international law in accordance with international conventions. And in accordance with the local laws issued by Egypt on the protection of antiquities and the fight against corruption, especially Law 117 of 1983 and amended by Law 3 in 2010 and its executive regulations and the provisions of the decisions of the Minister of Culture in this regard and Law 119 of 2008, with declaration of the establishment of the National Organization for Urban Harmony, Which is based on the protection of buildings and real estates.
\end{abstract}

KEYWORDS: Revolution, Violations, Heritage Buildings, Deterioration, Removal, Sustainable, Revival, Conservation.

Forms of land and building violations:

Violations on agricultural land: 


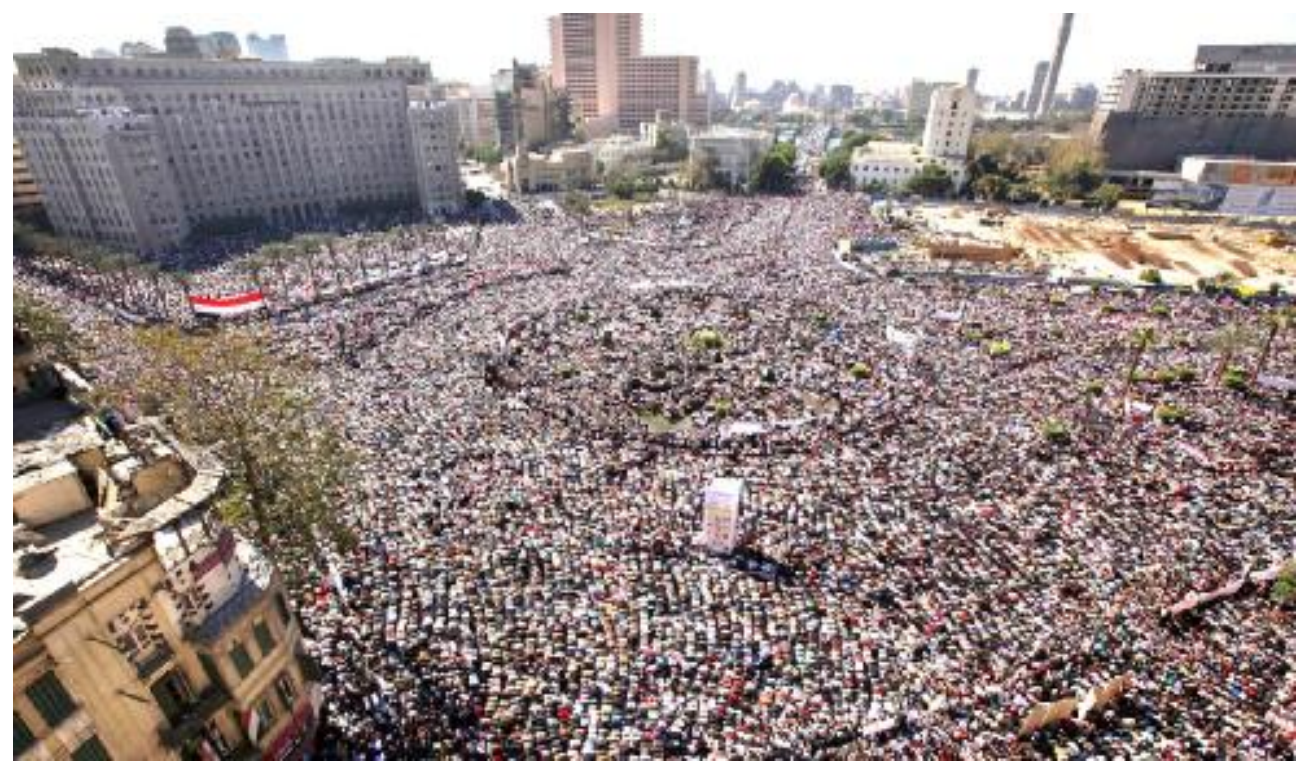

Fig (1) Photo showing the amount of people in Tahrir Square during the January 2011 revolution

The committees of the Ministry of Agriculture have to know the violations on the agricultural lands and with the coordination with the various other agencies in the state could not to connect all utilities and consequently, the government has not connected the water and electricity to These lands.

The committees of the Ministry of Agriculture made a record of the violations which happened on the agricultural land in preparation for the removal operations using heavy equipment.

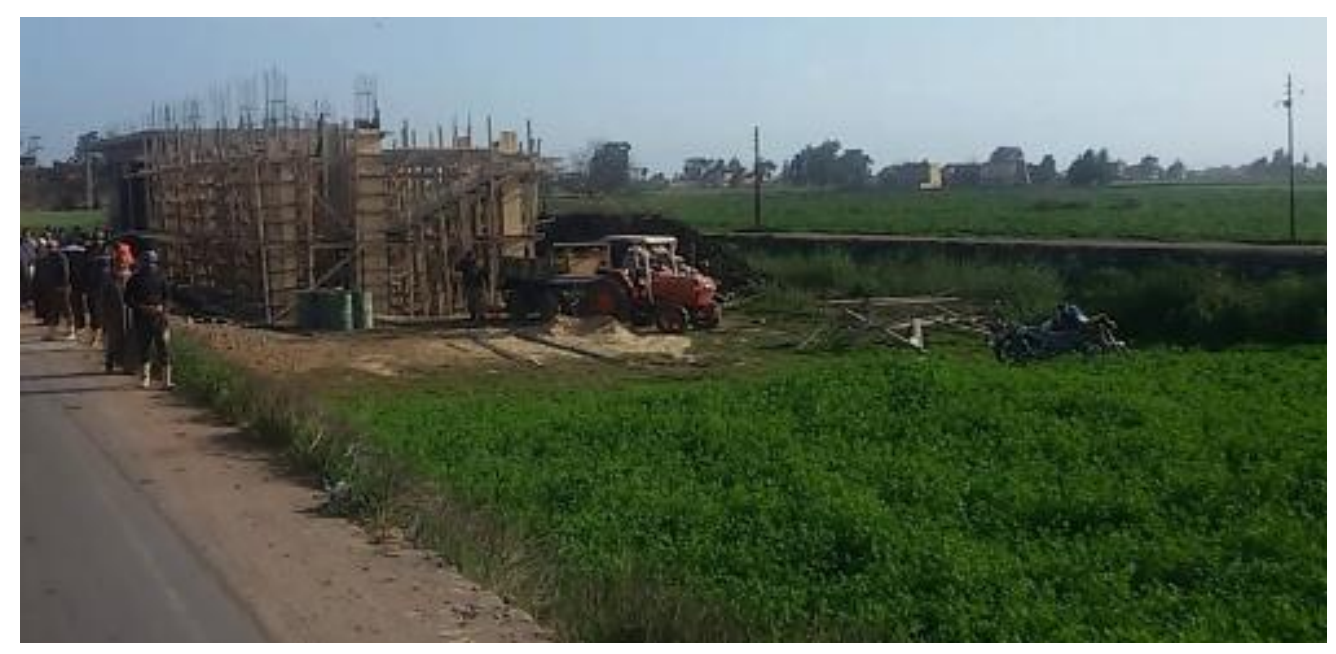

Fig (2) Constructions on agricultural land in all governorates of Egypt

The total number of violations since the January Revolution 2011 has reached 2 million and 727,141 cases on an area of 76,788 feddans. 
- Violations of Historical and heritage buildings:

After the revolution of January 2011, the cities of Egypt were faced violations on Historical and heritage buildings, either by demolition, distortion, floor additions or unfair reuse.

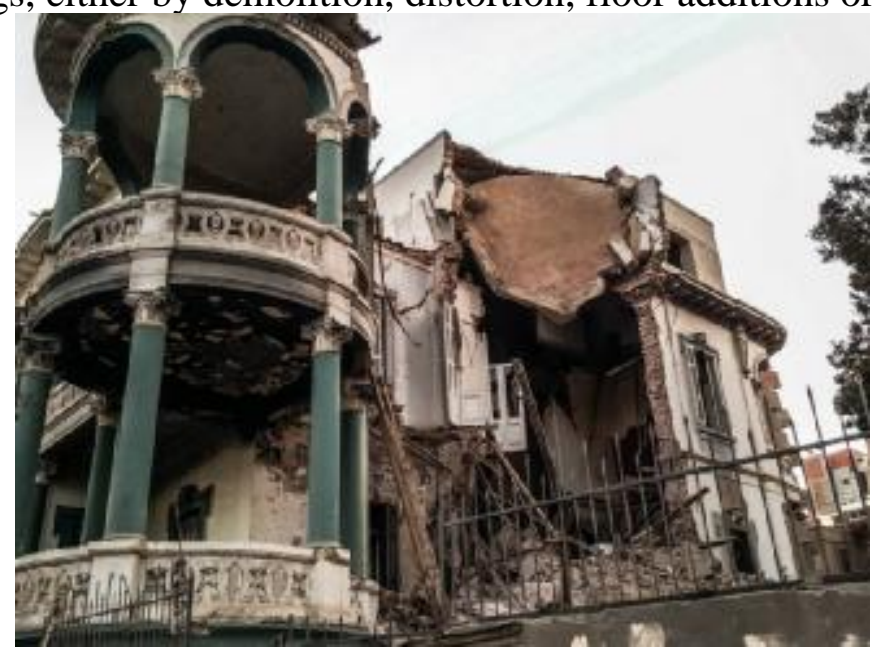

Fig (3) Demolition of heritage buildings during the January 2011 revolution

We find that many of the historical buildings were deteriorated either through the violations of individuals on them by housing or through government agencies. In addition, the residents and occupants of the historical buildings carried out violations on the buildings without any supervision and some of the buildings were used by as Industrial workshops, which leads to the rapid deterioration of the buildings on the other hand, many government agencies are using those buildings in service projects as schools or health units or public stores without taking into account the preservation and maintenance of the buildings.

The heritage of the sites has been distorted due to the spread of new architectural buildings with poor quality in terms of architectural design, which has distorted the visual image of heritage areas.
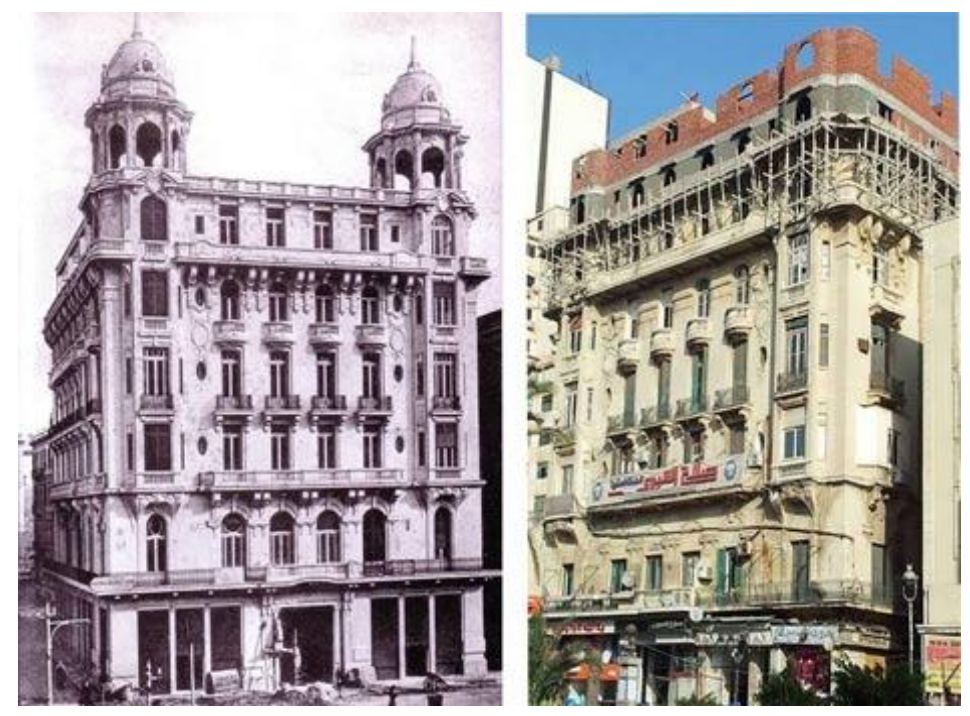

Fig (4) Violations of heritage buildings within adding some floors

Based on the results of the preservation committees in Alexandria, the owners of 52 registered buildings removed them from the preservation of heritage, after obtaining judicial permeation, 
and 33 were demolished during the past seven years, converted from art pieces to towers high without aesthetic touch.

- Violations with new residential and public buildings:

These violations appear in the form of buildings that was built without Building Permit, whether residential, commercial or industrial buildings, and are more visible in random housing and inner-spaces.

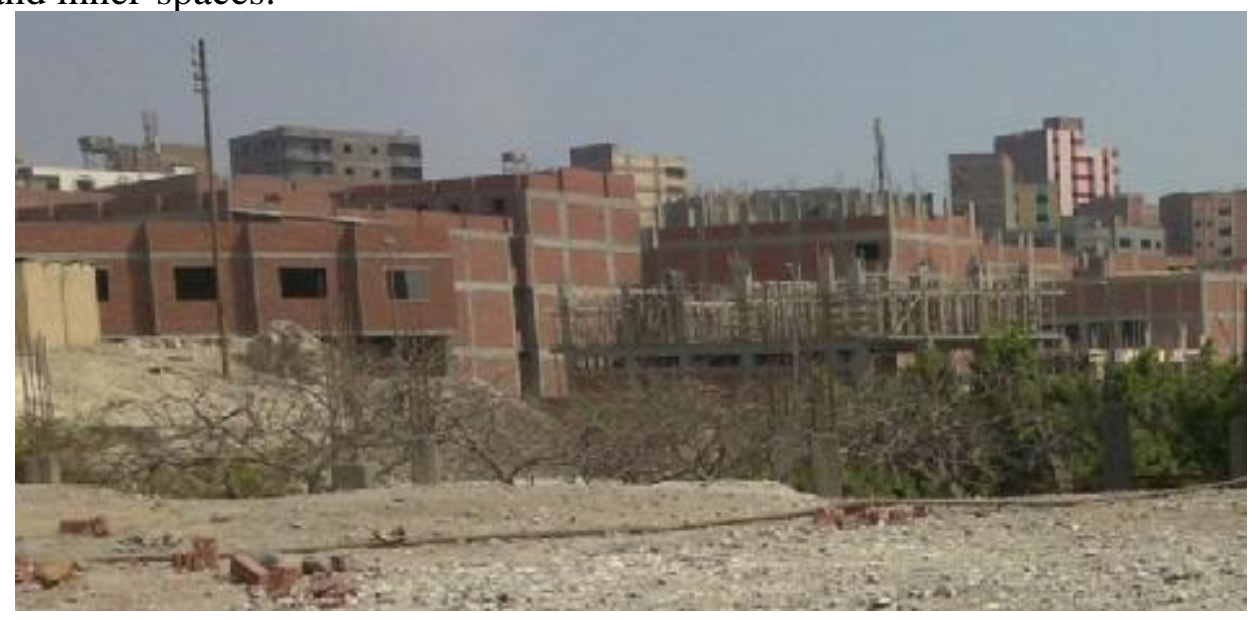

Fig (5) Building new buildings without building permits and randomly

- Violations on cemetery:

These violations occurred from long time in the 1970s due to the deterioration of the condition of residential buildings, many of which were impassable. The people were able to stay in mosques and cemeteries in large part. They initially started as temporary but with the lack of housing they became permanent residents.

This violation was on all types of cemeteries, including heritage tombs and royal cemeteries. The population of the graves so far according to the latest statistics of the Central Agency for mobilization and statistics to 5 million people.
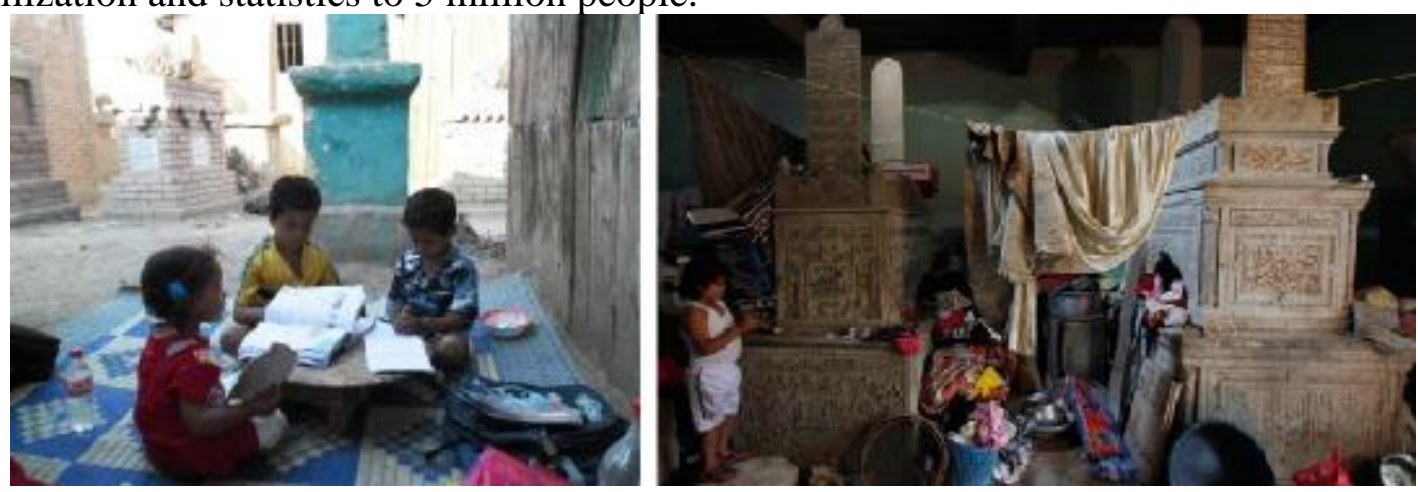

Fig (6) Picture showing the population of the graves, which reached 5 million people

\section{- The burning of buildings in Egypt during the revolution of January:}

During the demonstrations in Egypt and the strikes, many buildings were burned, such as government buildings and public buildings, for example the building of the scientific Complex, Elhazb El Watany El Demokraty-Party building, the Suzanne Mubarak libraries in the Giza Corniche, other areas and some mosques and churches. 


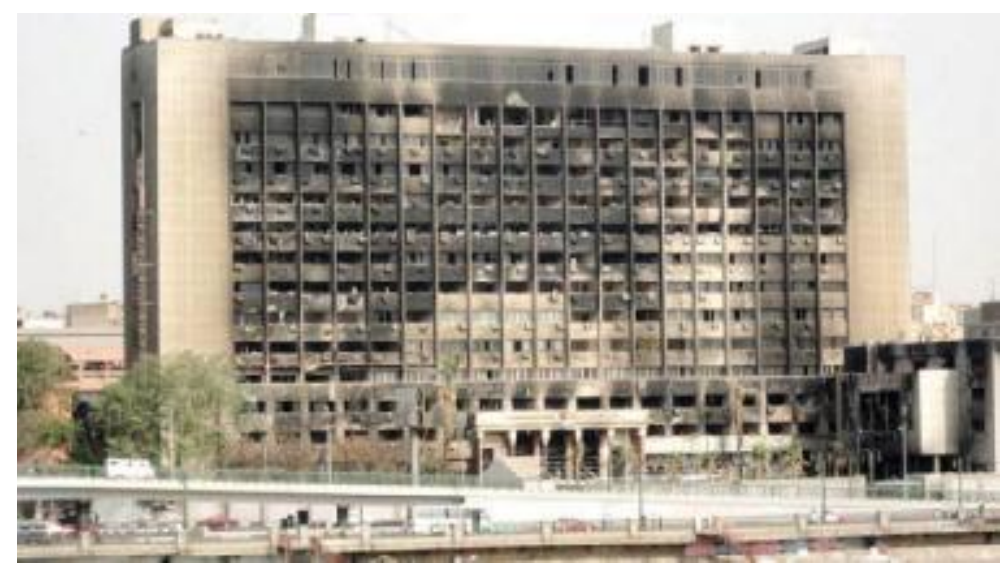

Fig (7) The burning of the National Party building during the January 2011 revolution

\section{Actions of the Egyptian state to overcome the damage and violations after the revolution of January 2011: \\ - Removal of violations from Egyptian state lands:}

Ministry of Local Development confirmed that 85,000 cases have been removed, representing $42 \%$ of the cases of violations observed by the ministry's operations rooms.
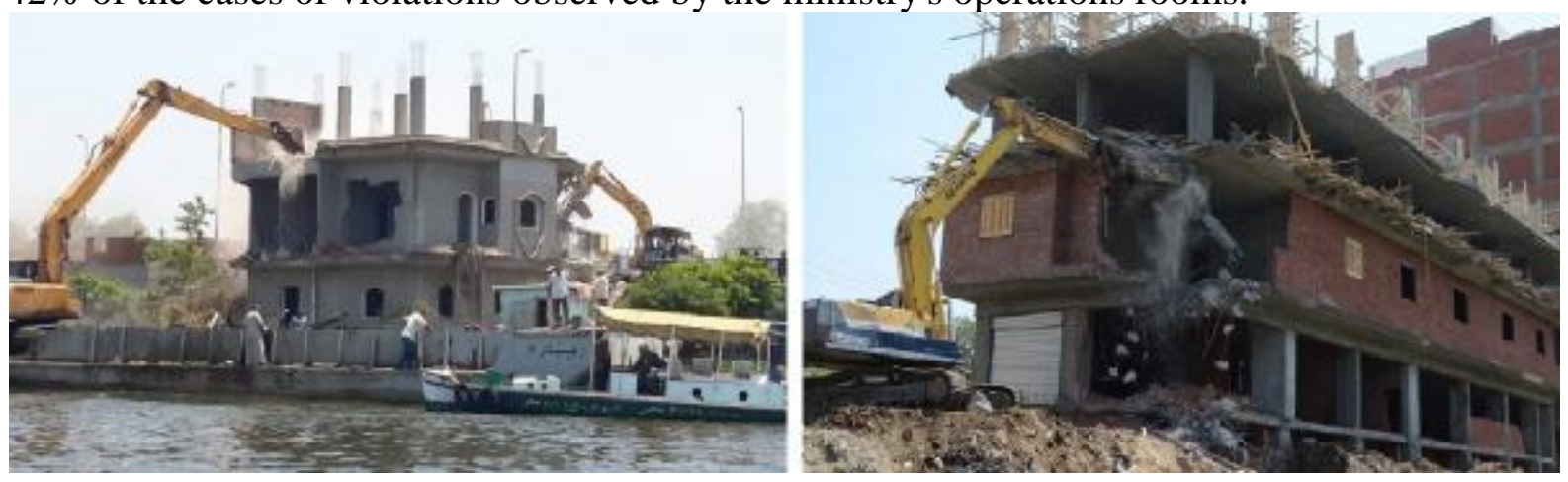

Fig (8) Removing the encroachments from the agricultural land and from the banks of the rivers

For example, the violations of Assiut governorate has been removed of 209 cases from the state land in four centers are Abnob, Fath, Bedari and Ghanaim.

Albehera governorate was removed 1890 cases on the agricultural land.

Fayoum governorate has achieved the removal of 5381 cases violated in various forms, including agricultural lands, including waterways and nature reserves.

Three cases have been removed in North Sinai on the state lands, and efforts in Menoufia resulted the implementation of 121 removal orders, and the governorate of Minya was removed 20144 cases violated in various forms. 30 cases were removed from the city of Abu Qurqas and 10 cases were removed from the historical lands of Bahnasa. Qena governorate 7994 cases were removed on agricultural land and building land.

\section{- Removal of the burning building of Elhazb EI Watany EI Demokraty-Party:}

The headquarters of the dissolved Elhazb El Watany El Demokraty-Party was exposed to fire more than 50 hours, during two days 28,29/2011. The building included the headquarters of Elhazb El Watany El Demokraty-Party, the National Council for Women, the Supreme Press Council, its historic archives and a number of government authorities. 


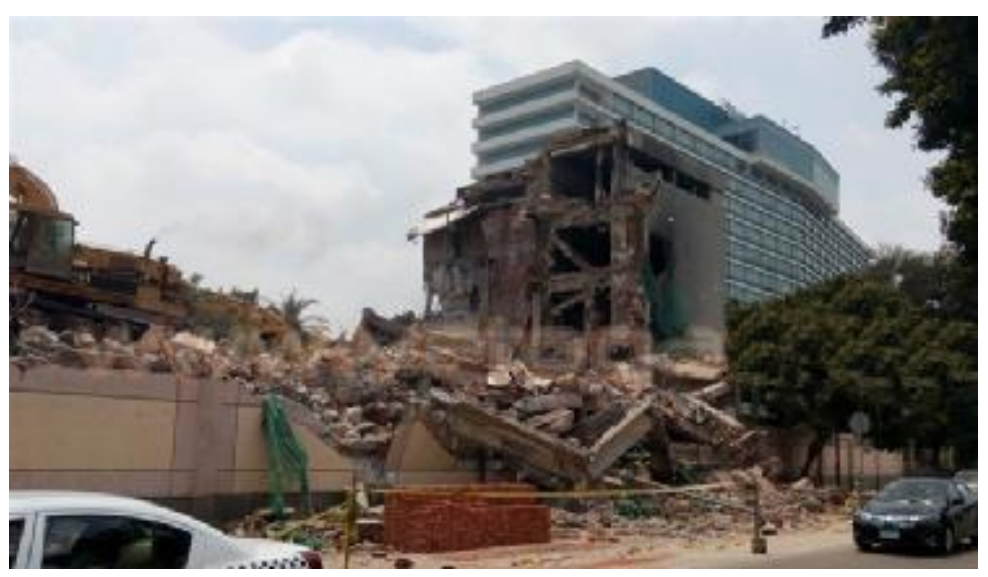

Fig (9) Demolition of Elhazb El Watany El Demokraty \& the National Council for Women

The building dates back to the 1950s, the site on the demolished English Church building to be the headquarters of the Socialist Union. The church building was the headquarters of the English intelligence archive in Egypt.

\section{- Activating the role of green and sustainable architecture principles:}

Green architecture is an environmentally friendly architecture whose goal is to achieve less waste of natural resources and less pollution and environmental waste.

Green architecture is not luxury or rich, but it is necessary to preserve the environment in which we live, and save a lot of cost of water consumption, electricity and energy.

Under this notice, the state has revived environmentally friendly projects like:

\section{- Reviving and restoring the village of Hassan Fathi in Qurna:}

The importance of Hassan Fathi's legacy in architecture is regarded as a unique example of the poor's and sustainability in architecture. The restoration of Hassan Fathi village in Kurna consists of four stages: restoration, conservation, ways to prevent violations, reuse of the village buildings, and training of the village builders in the style of Hassan Fathi building, restoration and maintenance. The first phase of the project includes the rehabilitation of the house of Hassan Fathi, the market in cooperation between the Ministry of Culture and UNESCO, and the problems facing the project, the most important of which are groundwater and sewage.
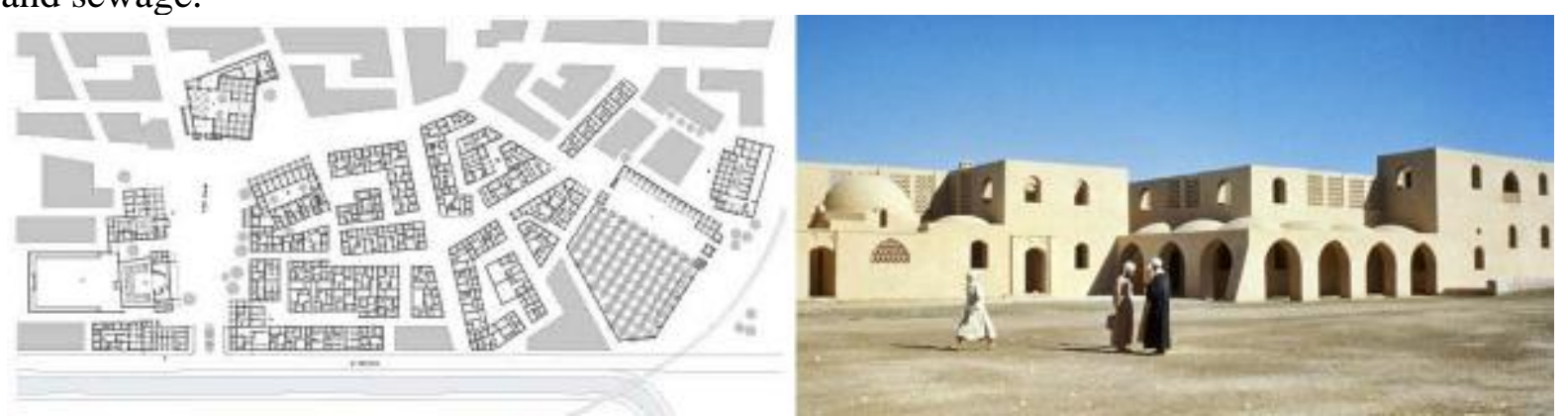

Fig (10) The renovation of Hassan Fathi village in Kurna 


\section{The large Egyptian Projects with high investments: \\ - New Administrative Capital:}

The administrative capital is a large-scale project announced by Minister of Housing Mustafa Madbouli at the Conference on the Support and Development of the Egyptian Economy on March 13, 2015.

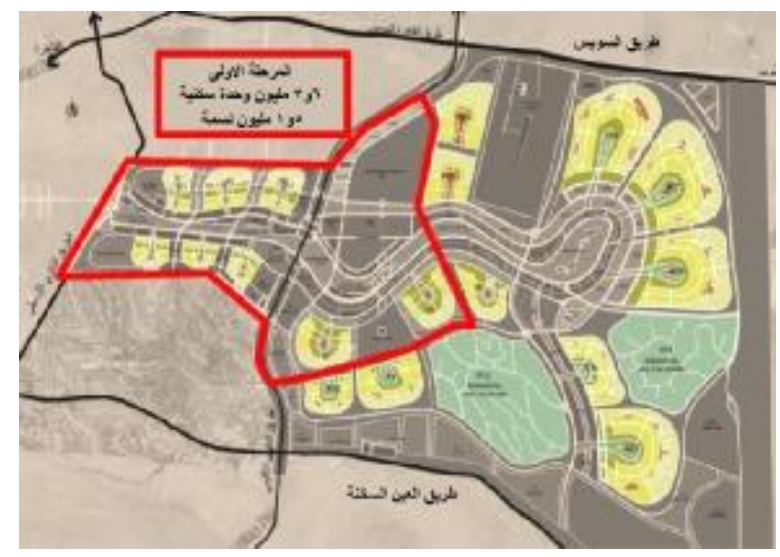

Fig (11) The first phase of the new administrative capital

The new city will be located east of Cairo and within the city of Cairo and within the Greater Cairo area on the second ring road in the middle of the road area is currently extended the port of the city of Suez. So it is a part of the city Cairo and will be the area of the headquarters of government departments and ministries, as well as foreign embassies. The site of The administrative capital about 700 square kilometer (300 square mile) total area, it will provide housing for up to five million people. The proposal also includes a main theme park and a new international airport. At present there is an airport used by the Egyptian Air Force. The parliament, presidential palaces, government ministries and foreign embassies are to be completed between 2020 and 2022 at a cost of 45 billion $\$$.

\section{- Project of the New Channel of Suez Canal:}

The government has collected 64 billion pounds through investment certificates at an annual interest rate of $12 \%$ for a period of 5 years. The proceeds are paid every 3 months and by the Suez Canal Authority.

The remainder was channeled to the construction of 6 tunnels under the Suez Canal, 3 at Port Said and 3 at Ismailia. The new Channel of Suez Canal is a new canal for the Suez Canal from $61 \mathrm{~km}$ to $95 \mathrm{~km}$. Was inaugurated on August 6, 2015 with a length of $35 \mathrm{~km}$, in addition to the expansion and deepening of the lakes and the length of $37 \mathrm{~km}$ to the total length of the project $72 \mathrm{~km}$ from $50 \mathrm{~km}$ to $122 \mathrm{~km}$.

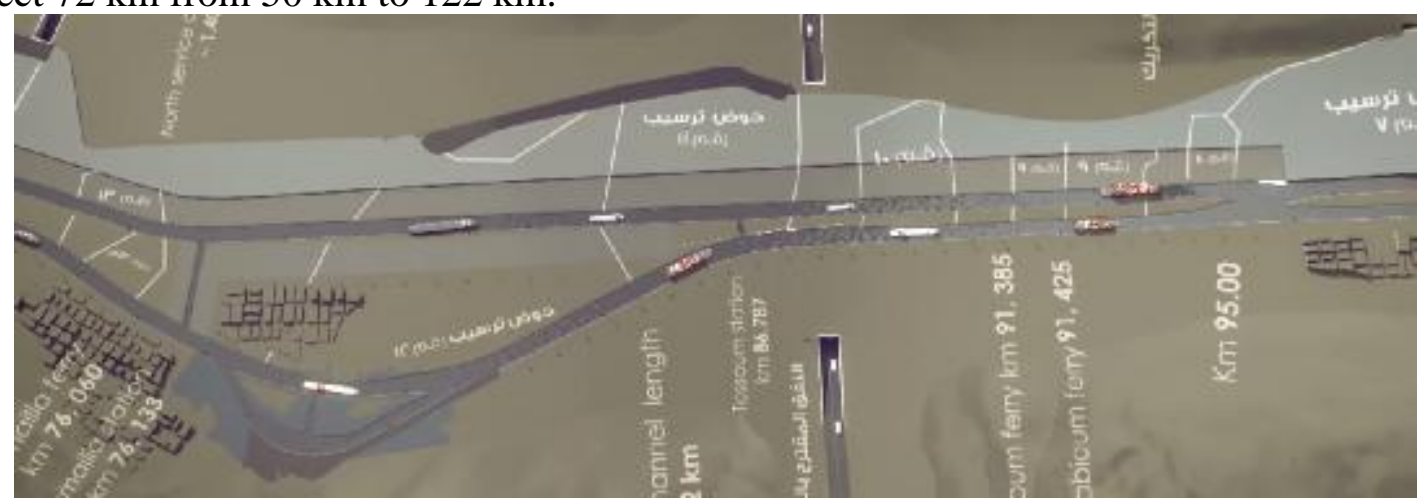

Fig (12) The new Channel of Suez Canal which allowed to the mega ships with a 65-foot depth 
The new canal project aims at avoiding the old problems of the Suez Canal from stopping the North container ships for more than 11 hours in the waiting lakes. The Suez Canal is allowed to accommodate the mega ships with a 65 -foot depth at a cost of 4 billion dollars, which will increase the channel's income by $259 \%$. Drilling operations through the Engineering Corps of the Armed Forces, which used 17 national civil companies operating under its supervision.

The government data in the economic and social development plan for the year 2015-2016 showed Suez Canal revenues after the start of the new channel estimated at 5.5 billion $\$$, an increase of 100 million $\$$. The plan also showed expectations of a decrease in the volume of vessels passing through the canal and increasing ship loads.

- Mohammed Najib Military Base Project:

It was opened in May 2017, its mission is to secure the Dabaa nuclear plant, oilfields and western borders of Egypt. It includes 1155 buildings and facilities. It includes 451 modern tankers. It includes 72 integrated training fields, including two residential cities for officers and noncommissioned officers. It also contains houses a multi-purpose conference hall with 1,600 people. A Mosque for 2000 prayers and 50 solar modules for electricity.

\section{- Dabaa Nuclear Energy Project:}

Egypt is now on the run of the establishment of the first peaceful plant for nuclear power to generate electricity at the station Dabaa in Matrouh governorate. The first stage is to build a plant with four nuclear power plants with a total capacity of 4800 megawatts to be implemented in cooperation with the Russian side and the cost of the station will be 29 billion Dollars.

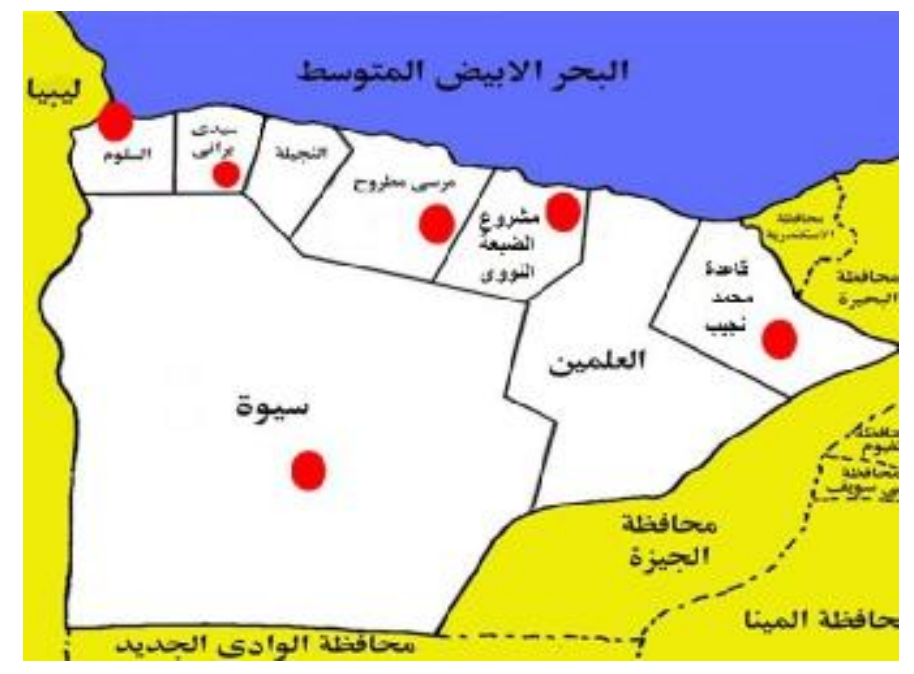

Fig (13) Dabaa nuclear project \& Mohammed Najib Military Base

The first contract which included an agreement to build a nuclear power plant in Dabaa between Egypt and Russia was in November 2015, which includes four reactors with a capacity of 1200 megawatts, with Russia providing a loan to Egypt to finance the construction of this project.

It is scheduled to start construction in the next few months, the first unit will be operated in 2022, and the rest in 2026.

- Nile water supply project to Sinai (Sarabium Sahara):

The project works to provide the main elements for the development of real and sustainable people of Sinai and to enable people to live and invest in agriculture and industry and economic development.

The project can be planting and irrigation of about 70: 100 thousand feddans in Sinai. 


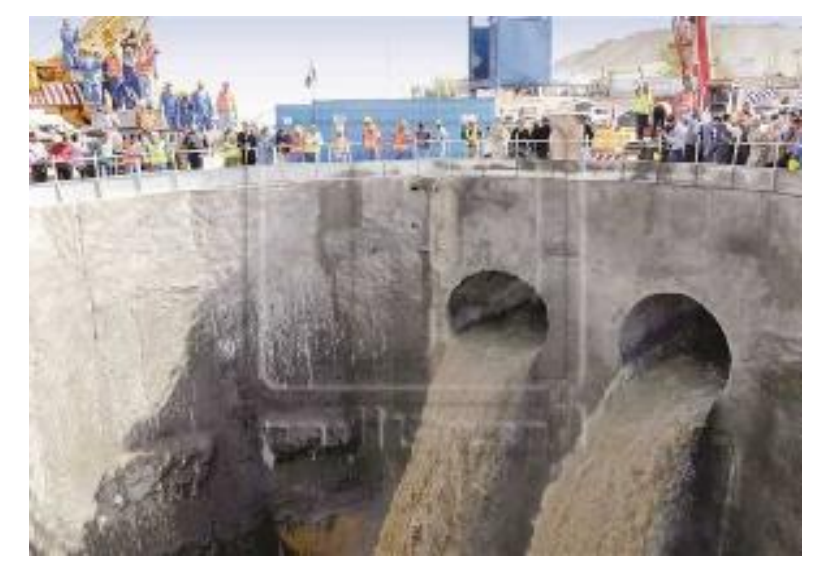

Fig (14) Nile water supply project to Sinai (Sarabium Sahara)

The drone consists of 4 massive water receiving and the depth of wells, of 60 meters, with a diameter of about 20 meters, with four horizontal tunnels. The length of the tunnel is 420 meters, under the Suez canal. The tunnel diameter is 4 meters, and below the water level with 60 meters.

\section{CONCLUSION:}

The January 2011 revolution has its disadvantages and advantages. disadvantages were appeared in violations on agricultural lands and on the banks of waterways, construction of new buildings without permits and infringement of archaeological and heritage buildings, the reaction to these infringements was the removal, modification and repair of these situations, as well as new projects Which has helped to attract investment in all areas of life. In conclusion, the January 2011 revolution had negative effects and positive effects, which made a significant improvement in the conditions of urbanization in Egypt.

\section{REFERENCES:}

1. The General Plan for the Preservation of the Cultural Heritage - Dr. Saleh LMae Mustafa - 2008.

2. Dr. Suheir Zaki Hawass - Cairo Khedive - Monitoring and Documentation Architecture and Urban of Cairo - Downtown - Center for Architectural Design - First Edition 2002

3. Ayman Fouad Sayed - Urban Development of Cairo since its inception and until now - The Egyptian Lebanese House - First Edition 1997.

4. Abbas El Tarabili - Streets with a History - The Egyptian Lebanese House - First Edition 1997.

\section{Web sites:}

25 January reveloution https://ar.wikipedia.org/wiki/ تورة_ 7/2018

National Organization For Urban Harmony http://urbanharmony.org/ar_home.asp - 7/2018

National Organization For Urban Harmony

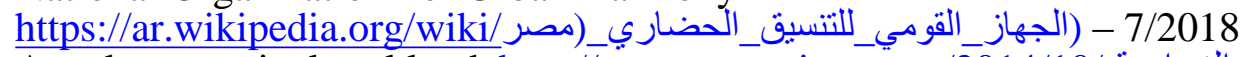

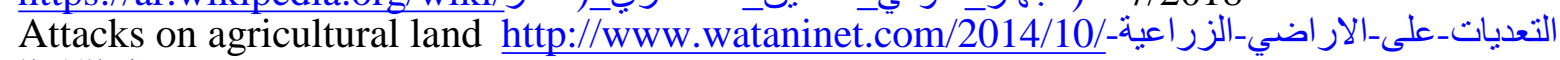
r.VY07/ب- Tستمر - 7/2018

Building infringements on agricultural land

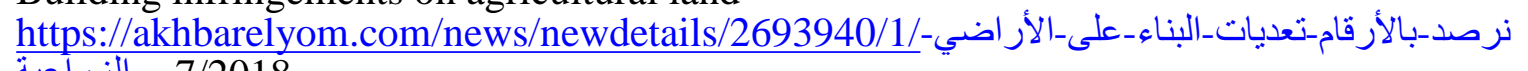
7/2018

مافيای-هدم-1/20molition of heritage buildings https://www.youm7.com/story/2015/11/12

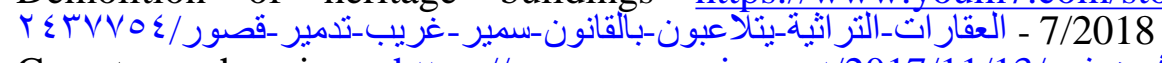

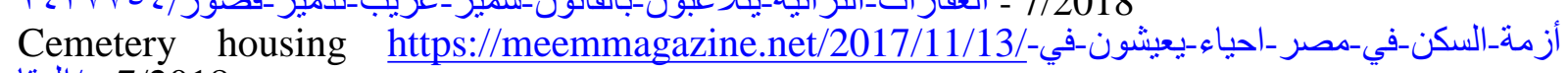
الدقا: - 7/2018 
موجة-10moval of encroachments on state lands https://www.youm7.com/story/2018/5/10

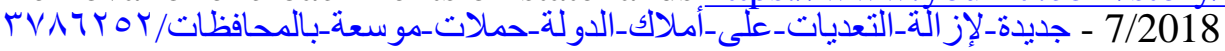

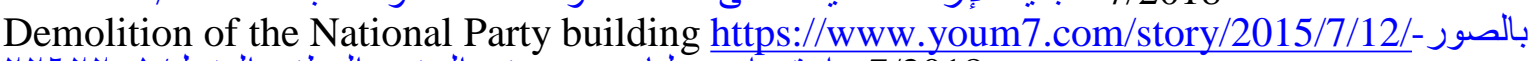

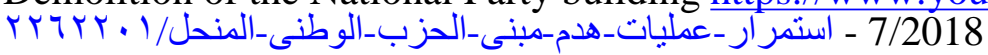

Reviving the village of Qurna https://www.youm7.com/story/2018/1/5/عور -عمال-مدينة_القرنة

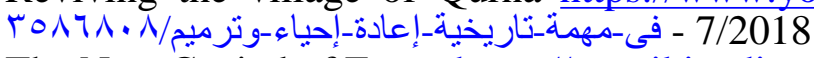

The New Capital of Egypt https://en.wikipedia.org/wiki/Proposed_new_capital_of_Egypt $7 / 2018$

New Suez Canal https://en.wikipedia.org/wiki/Suez_Canal_Area_Development_Project $7 / 2018$

Mohammed Najib Military Base http://www.arabnews.com/tags/mohammed-najib-militarybase - 7/2018

Dabaa Nuclear Power Plant https://en.wikipedia.org/wiki/El_Dabaa_Nuclear_Power_Plant $7 / 2018$

Transfer of Nile water to Sinai

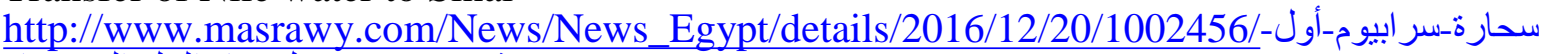
7/2018 - مشروع-قومي-ينقل-مياه-النيل-إلى-سيناء//. 